\section{Impact of AVG Preharvest Spray and Soil Injection on Yield and Quality of Melon}

\author{
Daniel I. Leskovar \\ Texas Agricultural Experiment Station, Vegetable and Fruit Improvement \\ Center, Texas A\&M University, 1619 Garner Field Road, Uvalde, TX 78801
}

\author{
Smiljana Goreta \\ Institute for Adriatic Crops, Put duilova 11, Split 21000, Croatia
}

\author{
Jose A. Franco \\ Universidad Politecnica de Cartagena, Departamento de Produccion \\ Vegetal, Paseo de Alfonso XIII, 52, 30203 Cartagena, Spain
}

Additional index words. Cucumis melo, ethylene, firmness, muskmelon, ripening

\begin{abstract}
The aim of this study was to determine whether aminoethoxyvinylglycine (AVG), an inhibitor of ethylene synthesis, would affect earliness, increase yield, and improve overall at harvest and postharvest quality of melon (Cucumis melo $\mathrm{L}$. group Cantalupensis, 'Sol Real'). Field experiments were conducted during two seasons with AVG (124 g.ha ${ }^{-1}$ a.i.) applied as spray or soil injected into the root zone with a single or double application between $7 \mathrm{~d}$ and $21 \mathrm{~d}$ before harvest. The AVG soil injection method increased earliness compared with AVG spray in one season. Total marketable yield increased with AVG injection but not with the AVG spray method compared with the control. Regardless of method of application, AVG did not affect fruit firmness, rind thickness, netting, or soluble solids content when measured at harvest. However, AVG spray decreased fruit size and seed cavity in one season. Similarly, AVG spray did not affect fruit quality after storage, whereas AVG soil injection increased fruit firmness. Overall, melon yield and fruit quality responses to preharvest AVG applications were superior for the soil injection than the spray method.
\end{abstract}

Melon (Cucumis melo L.) fruit ripening is not uniform because of the extended flowering, pollination, and fruit set period. The onset of harvest maturity coincides with the development of an abscission zone between the peduncle and fruit, and with an increase in ethylene concentration inside the fruit (Rowan et al., 1969; Yang and Hoffman, 1984). The ripening process in melon includes an ethylene-dependent fruit-softening phase followed by an activation of the peduncular abscission zone, and an ethyleneindependent flesh pigmentation phase (Ayub et al., 1996). In addition, ethylene production in melon fruit appears to be the most important factor in determining postharvest decay severity (Zheng and Wolff, 2000). The internal ethylene concentration is less than 10 ppb during most of the fruit growth; however,

Received for publication 13 Mar. 2006. Accepted for publication 27 Apr. 2006. The authors thank K. Kolenda for her valuable technical help. Appreciation is also extended to Valent BioSciences Corp., Libertyville, Ill. and to US Department of Agriculture grant (CSREES 2003 34402-13647 "Designing Foods for Health") for partial funding. Mention of a trademark, proprietary product, or vendor does not constitute a guarantee or warranty of the product, nor does it imply approval or disapproval to the exclusion of other products or vendors that may also be suitable.

${ }^{1}$ To whom reprint request should be addressed; e-mail d-leskovar@tamu.edu upon reaching $10 \mathrm{ppb}$ it sharply increases in most cultivars in a typical climacteric fashion (Miccolis and Saltveit, 1991). It is wellknown that rates of ethylene production and internal concentrations differ among cultivars (Miccolis and Saltveit, 1991; Silva et al., 2004). Orange-flesh cultivars produce more ethylene than green- or white-flesh cultivars, whereas netted fruits produce more ethylene than smooth types (Zheng and Wolff, 2000).

Aminoethoxyvinylglycine (AVG) inhibits ethylene biosynthesis by blocking the synthesis of 1-aminocyclopropanecarboxylate synthase (Yu et al., 1979), the enzyme that promotes 1-aminocyclopropane-1-carboxylic acid conversion to ethylene (Abeles et al., 1992). The potential commercial value of AVG spray application timing has been well documented for fruit trees (Abeles et al., 1992). In peach, Belding and Lokaj (2002) showed that an early application of AVG (21 $\mathrm{d}$ before harvest $[\mathrm{DBH}]$ ) delayed fruit maturity whereas a late application $(7 \mathrm{DBH})$ reduced ethylene production and sustained postharvest fruit flesh firmness. In apples, AVG delayed preharvest fruit drop and maturity, and reduced internal ethylene concentration (Schupp and Greene, 2004) and, as a consequence, delayed onset of the ethylene climacteric stage (Greene and Schupp, 2004). In melon, Shellie (1999) reported that when AVG was sprayed at $260 \mathrm{mg} \cdot \mathrm{L}^{-1}\left(125 \mathrm{~g} \cdot \mathrm{ha}^{-1}\right.$ a.i.) either 18 or $12 \mathrm{DBH}$, it delayed the development of fruit abscission zone, and that AVG-treated melons had lower ethylene production at harvest and after cold storage. Generally, AVG is applied as preharvest spray in peaches, apples, and melons (Belding and Lokaj, 2002; Greene and Schupp, 2004; Schupp and Greene, 2004; Shellie, 1999) or as a fruit dipping after harvest (Byers, 1997). The effectiveness of AVG when applied to the root zone is unknown, but there is some speculation that AVG can be rapidly taken up by roots and translocated to the rest of the plant (Valent BioSciences Corp., Libertyville, Ill, personal communication, 2000). Application of AVG at the root zone has an ability to reduce transpiration under drought stress and hence postpone water deficit (Islam et al., 2003). However, there is not information on how AVG applied through this method may affect fruit responses at maturity. The aim of this study was to determine the effectiveness of two AVG methods of applications - spray (conventional) and drip (potentially novel) - and timing on earliness, marketable yield, and fruit quality at harvest and after cold storage.

\section{Material and Methods}

Plant material and cultural practices

Field experiments with the early-maturing western shipper melon cv. 'Sol Real' were conducted at the Texas A\&M University, Texas Agricultural Experiment Station in Uvalde $\left(29^{\circ} 1^{\prime} \mathrm{N}, 9^{\circ} 5^{\prime} \mathrm{W}\right)$ during 2000 and 2002. The soil was a Uvalde silty clay loam (fine silty, mixed, hyperthermic Aridic Calciustoll; $\mathrm{pH}, 7.7$; organic matter, $2.3 \%$; with a textural analysis of $9 \%$ sand, $55 \%$ clay, and $36 \%$ silt $)$. Preplant fertilizer $(48 \mathrm{~N}-21 \mathrm{P}+2 \mathrm{Zn}$ $\mathrm{kg} \cdot \mathrm{ha}^{-1}$ ) was broadcasted and incorporated into the soil both years. Additional fertilizer $\left(40 \mathrm{~N}-10.9 \mathrm{P}-76.4 \mathrm{~K} \mathrm{~kg} \cdot \mathrm{ha}^{-1}\right)$ using potassium nitrate, phosphoric acid, and urea was injected (fertigated) weekly for 6 weeks or until first set fruits achieved half size. The crop was established by direct seeding on $14 \mathrm{Apr}$. 2000 and by transplants on 25 Mar. 2002. Each plot consisted of a single 15-m-long bed, $1.9 \mathrm{~m}$ apart with plants spaced $0.3 \mathrm{~m}$ along the row, with a total of 45 plants per plot. To ensure that lateral movement of AVG sprayed or injected into the soil through drip irrigation would not affect other treatments, plots were separated by adjacent 1.9-m blank rows.

A pair of tensiometers was placed in the middle of the row at $15 \mathrm{~cm}$ and $30 \mathrm{~cm}$ depth, and soil water potential was maintained above $-20 \mathrm{kPa}$ at $0.3 \mathrm{~m}$ depth from planting to first fruit set, and above $-60 \mathrm{kPa}$ thereafter. The field was irrigated with a subsurface drip tape $(0.2-\mathrm{mm}$ wall thickness) placed in the middle of the bed at $10 \mathrm{~cm}$ depth, with emitters spaced every $30 \mathrm{~cm}$ and a flow rate of $340 \mathrm{~L} \cdot \mathrm{h}^{-1}$ per $100 \mathrm{~m}$ of bed at $55 \mathrm{kPa}(\mathrm{T}$ Tape model TSX 508; T-systems International, Inc., San Diego, Calif.). The irrigation water requirement was supplied as described by Leskovar and colleagues (2001). Each individual plot was irrigated separately with on/off valves connected to the subsurface drip tubing with a submain line. Standard 
weed, insect, and disease control practices for melons were followed (Dainello, 1996).

\section{AVG application method and timing}

In both years, AVG (as ReTain, Valent BioSciences Corp., Libertyville, Ill.) at a rate of $124 \mathrm{~g} \cdot \mathrm{ha}^{-1}$ a.i., was applied as spray or injected into the root zone throughout a drip irrigation system as described later. Plots were sprayed with AVG at 21, 14, or 7 $\mathrm{DBH}$, or injected at $21 \mathrm{DBH}$. Also, repeated applications were performed with both methods at $21 \mathrm{DBH}$ and $14 \mathrm{DBH}$. Untreated control was sprayed or injected with water. Spraying was performed between 8:00 and 10:00 AM with a $\mathrm{CO}_{2}$ backpack sprayer delivering $270 \mathrm{~L} \cdot \mathrm{ha}^{-1}$ at $2.8 \mathrm{~kg} \cdot \mathrm{cm}^{-2}$ using three flat nozzles per bed, providing $\sim 20 \mathrm{~mL}$ solution per plant. A nonionic silicone-based surfactant (ABG-7011, Abbot Laboratories) at a rate of $0.5 \mathrm{~mL} \cdot \mathrm{L}^{-1}$ was used in all spray treatments including the control. Injection of the AVG solution was performed at the same time of day as spraying, using a proportional pump (Dosatron, Clearwater, Fla.) attached to the main drip irrigation system. Before injecting the AVG solution, all individual valves in each plot were manually closed except for the six (2000 season) or four (2002 season) valves in the plots allocated to the specific treatment. To ensure proper injection of the solution into the root zone, a 30-min water application was done before and after the AVG injection that lasted 1 hour. To avoid differences related to the amount of water delivered to plants for the AVG injection treatments, all other plots were irrigated for $2 \mathrm{~h}$.

\section{Yield and fruit quality}

Mature fruits were harvested four times from 3 July to 14 July 2000, and six times from 6 June to 26 June 2002. Fruits were harvested at the mature stage, the time when the abscission zone between the fruit and the peduncle was about between half to full slip stage. Marketable melons were classed according to the U.S. commercial trade standards (9-, 12-, or 15-count per 18-kg carton). Yield from the first two harvests in each year was assumed as early yield. Misshapen, damaged, blossom-end rot, and fruits below and above commercial categories were considered culls. At each harvest, fruit quality parameters were determined on two (early harvests) to five (peak harvests) class- 9 count fruits per plot, depending on the number of harvested fruits. Fruit diameter was measured at the equatorial part of the fruit. Soluble solids content was measured with a digital refractometer (PR-101; Atago Co. Ltd., Tokyo, Japan) using the hand-squeezed juice from equatorial sections of the mesocarp. Fruit netting uniformity was visually scored on a 1 to 5 -point scale ( $1=$ low, $5=$ high $)$, and seed cavity diameter was measured transversely with a digital caliper on half-cut fruits. Fruit firmness was measured after peeling off the exocarp on three random spots (located at the exposed surface) per fruit using a digital force meter (DFM 10; Chatillon, Greensboro, N.C.) with a 6-mm-diameter
V-head probe. Rind thickness was determined by measuring the exocarp width at three random spots on each fruit. In addition, three to five fruits per experimental unit from each harvest were stored at $5{ }^{\circ} \mathrm{C}$ for $14 \mathrm{~d}$ in 2000 and for $10 \mathrm{~d}$ in 2002 . Fruit quality parameters were measured as described earlier after removal from cool storage and equilibration for $1 \mathrm{~d}$ and $5 \mathrm{~d}$ at room temperature $\left(23^{\circ} \mathrm{C}\right)$ in 2000 and 2002 , respectively.

\section{Experimental design and data analysis}

The experiments were conducted using a randomized complete block design with six and four replications in 2000 and 2002 respectively. Data for yield and fruit quality parameters were subjected to analysis of variance using proc GLM SAS software (SAS Institute, Cary, N.C.). To compare and analyze differences between the control (no AVG) and AVG application methods and timings, a set of preplanned orthogonal contrasts were constructed for each measured parameter.

\section{Results and Discussion}

\section{Yield and fruit size}

Results of early yield, fruit class size, culls, and total marketable yields are presented based on the significance of the orthogonal contrasts (Table 1). Early yield in 2000 season was greater for the AVG injection method of application compared with the control $(P=0.018)$ or AVG spray $(P=0.001)$. Irrespective of application method, a delay in harvesting occurred in the double application of AVG $(21+14$ $\mathrm{DBH})$ compared with the single application $(P=0.009)$. Within AVG spray application treatments, the only significant difference was a delay in harvest at $14 \mathrm{DBH}$ compared with late $(7 \mathrm{DBH}, P=0.004)$ or early application (21 DBH, $P=0.036$; contrast not shown). AVG spray did not affect total marketable yield compared with the control $(P=0.600)$. Conversely, the AVG injection method had an increase in marketable yield compared with the control $(P=0.010)$ or spray application method $(P=0.001)$. Effects of methods of application and timing were significant for the class-9 fruits, which showed the same trends as total marketable yield. There were not significant differences in the 12 and 15-count fruit, or culls (Table 1). Similar to early yield, the AVG double application $(21+14 \mathrm{DBH})$ reduced class-9 fruit and total marketable yield compared with the single application.

In 2002, no significant differences occurred between the method of application treatments or timing for early yield, class-12, culls, and marketable yields (Table 1). Spray application of AVG reduced yield of class-9 count fruit size in comparison with the control $(P=0.010)$ or AVG-injected treatment $(P=0.008)$, but increased yield in class15 fruit. Yields for the single or double application of AVG were not significantly different, however the double application $(21+14 \mathrm{DBH})$ had an increase in class-15 $(P=0.001)$ fruit.

Comparing seasons, in 2000 there was a higher percentage of class- 9 count and less class- 12 count compared with the 2002 season. This shift in yield distribution (by size) toward a larger fruit size in the 2000 season could be related to differences in crop establishment, because it was reported that plants established by directed seeding generally had larger fruit size than melon plants established by transplants (Leskovar et al., 2001).

The role of ethylene in regulating plant growth and fruit development has been extensively studied for a variety of abiotic stresses and species (Abeles et al., 1992; Smalle and Van der Straeten, 1997). It is documented that ethylene concentration in melon fruit increases as fruits approach maturity. The delay in early harvest with AVG spray (conventional method of application) in 2000 , but not in 2002, could partially support the hypothesis that by blocking fruit ethylene production we may delay fruit maturity. The lack of increase in total marketable yields does not support idea that AVG spray application could extend fruit growth.

The effects of AVG spray application on yield were either negligible or negative in both years. No phytotoxic symptoms were observed in either year. Temporary leaf chlorosis at $62.5 \mathrm{~g} \cdot \mathrm{ha}^{-1}$ and $125 \mathrm{~g} \cdot \mathrm{ha}^{-1}$ AVG was noted in a study with melon (Shellie, 1999), whereas no toxicity symptoms were reported for apples at AVG rates from 50 to

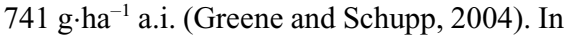
the field, plants are constantly exposed to different levels and sources of abiotic stresses, altering a single or complex hormonal balance. A specific plant hormone may influence the biosynthesis of another, or interfere in signal transduction pathways (Weyers and Paterson, 2001). In melon, the possibility that AVG spray contributes to hormonal imbalances that modify melon yield and quality is not known. Conversely, AVG injection into the soil through irrigation had a positive impact in the 2000 season, particularly for the early, class-9 count fruit, and total marketable yield. In 2002, this effect was also observed in class- 9 count fruit category compared with the AVG spray treatment. The positive result of enhancing melon yield with the AVG injection is a new finding. Evidence of AVG enhancing capacity on root and shoot growth of young barley seedlings and in white pine seedlings has been reported (Islam et al., 2003; Locke et al., 2000). It has been reported that AVG could also control other physiological or metabolic processes, including respiration and production of volatile compounds (Abeles et al., 1992). The possibility that AVG (or AVG signaling compounds) may affect some of these processes, including carbon allocation, or translocation from root to shoot, which in turn could enhance plant growth and positively modify yield and fruit quality in field environments, is intriguing. 
Table 1. Effects of AVG application method and timing (days before harvest [DBH]) on early, total marketable (size 9, 12, 15), and cull fruit yield of melon cv. 'Sol Real', Uvalde, Tex., in 2000 and 2002.

\begin{tabular}{|c|c|c|c|c|c|c|c|c|c|c|c|c|c|}
\hline \multirow{2}{*}{$\begin{array}{l}\text { AVG application } \\
\text { method }\end{array}$} & \multirow{2}{*}{ Timing, DBH } & \multicolumn{12}{|c|}{ Yield, $t \cdot h^{-1}$} \\
\hline & & \multicolumn{6}{|c|}{2000} & \multicolumn{6}{|c|}{2002} \\
\hline Control & & 12.6 & 22.8 & 2.2 & 1.7 & 7.9 & 26.7 & 15.6 & 20.7 & 10.6 & 2.0 & 3.1 & 33.7 \\
\hline & 7 & 14.1 & 27.0 & 4.1 & 1.3 & 8.2 & 32.4 & 8.0 & 16.2 & 11.6 & 3.2 & 4.1 & 30.3 \\
\hline & $21+14$ & 1.4 & 13.8 & 3.4 & 0.4 & 3.3 & 17.7 & 10.6 & 10.7 & 11.0 & 7.2 & 2.7 & 30.2 \\
\hline Injection & 21 & 24.9 & 35.2 & 6.3 & 0.8 & 8.6 & 42.3 & 14.9 & 20.0 & 12.2 & 3.0 & 3.9 & 35.8 \\
\hline Control vs. spray & & 0.074 & 0.590 & 0.584 & 0.088 & 0.154 & 0.600 & 0.143 & 0.010 & 0.451 & 0.001 & 0.700 & 0.159 \\
\hline Control vs. injection & & 0.018 & 0.010 & 0.125 & 0.073 & 0.578 & 0.010 & 0.729 & 0.633 & 0.453 & 0.075 & 0.968 & 0.675 \\
\hline Spray vs. injection ${ }^{\mathrm{w}}$ & & 0.001 & 0.002 & 0.222 & 0.602 & 0.090 & 0.001 & 0.394 & 0.008 & 0.673 & 0.004 & 0.597 & 0.064 \\
\hline Single vs. double ${ }^{v}$ & & 0.009 & 0.076 & 0.362 & 0.169 & 0.128 & 0.034 & 0.361 & 0.213 & 0.105 & 0.001 & 0.179 & 0.192 \\
\hline
\end{tabular}

${ }^{2}$ Yield of first two harvests.

${ }^{y}$ Fruits were classified according to the US commercial trade standards $(9,12$, and 15 fruits per 18-kg carton).

${ }^{x}$ Contrasts comparison were NS $(P>0.05)$ or significant at reported $P$ values.

"Spray application at 21 and $21+14 \mathrm{DBH}$ was compared with injection at 21 and $21+14 \mathrm{DBH}$.

${ }^{v}$ Single $=$ spray and injection application at $21 \mathrm{DBH}$; double = spray and injection application at $21+14 \mathrm{DBH}$.

Table 2. Effects of AVG application method and timing (days before harvest [DBH]) on fruit quality parameters at harvest and after cold storage of melon cv. 'Sol Real', Uvalde, Tex., in 2002.

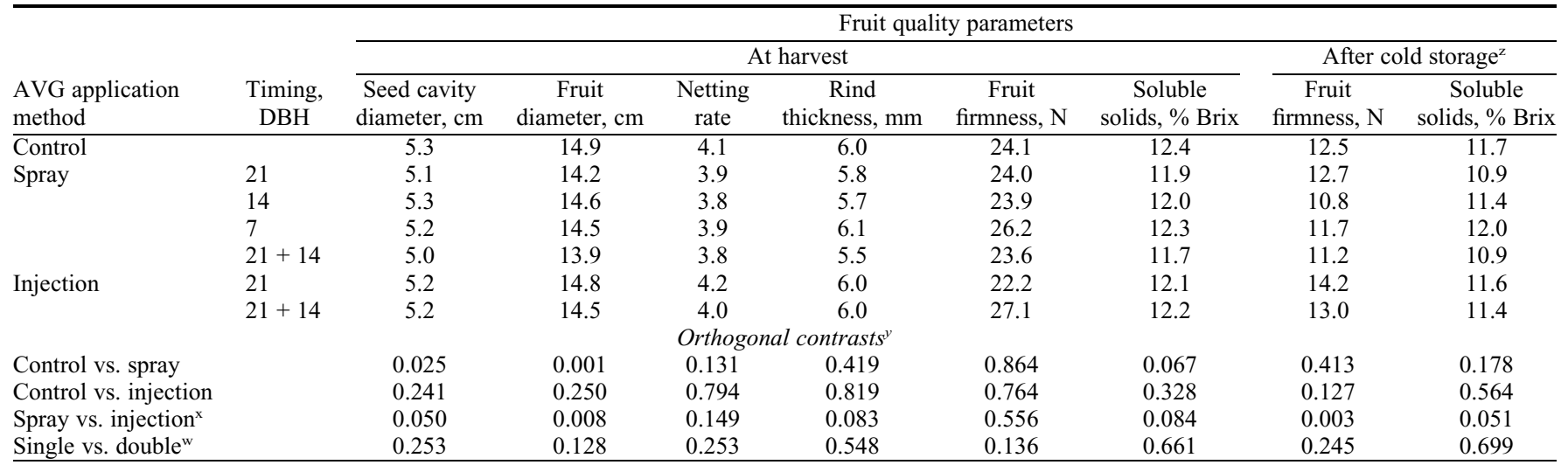

${ }^{2}$ Fruits were stored 10 days at $5{ }^{\circ} \mathrm{C}$ followed by $5 \mathrm{~d}$ at room temperature before measurements.

${ }^{\text {y }}$ Contrasts comparison were NS $(P>0.05)$ or significant at reported $P$ values.

${ }^{\mathrm{x}}$ Spray application at 21 and $21+14 \mathrm{DBH}$ was compared with injection at 21 and $21+14 \mathrm{DBH}$.

${ }^{\mathrm{w}}$ Single $=$ spray and injection application at $21 \mathrm{DBH} ;$ double $=$ spray and injection application at $21+14 \mathrm{DBH}$.

\section{Fruit quality at harvest and after storage}

Fruit quality characteristics were stable during the harvest periods in both years and date of harvest did not interact with the AVG treatments for the examined fruit parameters. Pooled across all harvests during the 2000 season, the method or timing of AVG application did not affect fruit diameter, fruit firmness, netting rate, rind thickness, or soluble solids content (data not shown). The same trends were found in 2002, except for the seed cavity and fruit diameter at harvest (Table 2). Seed cavity was reduced $(P=$ $0.025)$ for sprayed fruits compared with control fruits. Fruit diameter was also smaller for AVG-sprayed fruits in comparison with the control $(P=0.001)$ and AVG-injected treatments $(P=0.008$; Table 2$)$. After cold storage, fruit firmness for the AVG injection treatments increased about $14 \%$ compared with AVG-sprayed treatments $(P=0.003)$.

Reduction of fruit internal ethylene concentration as a consequence of AVG preharvest spray application has been shown in fruit trees (Belding and Lokaj, 2002; Greene and Schupp, 2004; Schupp and Greene, 2004) as well as in melons (Shellie, 1999). However, in the latter study with melons, no apparent positive effect of AVG spray (125 g.ha ${ }^{-1}$ a.i.) was found on fruit quality at harvest or after storage. These results are in agreement with our findings. Therefore, it is difficult to explain the lack of AVG spray response of melon fruits based on lower internal ethylene concentration. Miccolis and Saltveit (1991) reported that melon fruit softening and soluble solids content increase preceding the increase in internal ethylene concentration. Fruit ripening was delayed in transgenic melon plants with reduced ethylene production, and this effect was accompanied by increased fruit firmness and extended storage life (Ayub et al., 1996; Silva et al., 2004). Therefore, it seems the pattern of the melon ripening mechanism is very difficult to alter or stop once triggered. We conclude that AVG spray did not result in a consistent yield or fruit quality improvement. Our results do not support the pre- harvest application of AVG spray in melons. Considering the AVG injection method, the yield improvement in the class- 9 fruits $(75 \%$ and $52 \%$ over AVG spray in both seasons, and $49 \%$ over the control in the first season) provides evidence for additional examination of this application method across a wider array of field environments.

\section{Literature Cited}

Abeles, F.B., P.W. Morgan, and M.E. Saltveit. 1992. Ethylene in plant biology. Academic Press, San Diego: Calif.

Ayub, R., M. Guis, M. Ben Amor, L. Gillot, J.P. Roustan, A. Latche, M. Bouzayen, and J.C. Pech. 1996. Expression of ACC oxidase antisense gene inhibits ripening of cantaloupe melon fruits. Nat. Biotechnol. 14:862-866.

Belding, R.D. and G.R.W. Lokaj. 2002. Aminoethoxyvinylglycine treatment of peach fruit reduces ethylene production and softening. HortScience 37:1065-1068.

Byers, R.E. 1997. Peach and nectarine fruit softening following aminoethoxyvinylglycine sprays and dips. HortScience 32:86-88. 
Dainello, F.J. 1996. Texas commercial vegetable production guide. Texas Agricult. Ext. Serv., Texas A\&M Univ. System, College Station, Tex.

Greene, D.W. and J.R. Schupp. 2004. Effect of aminoethoxyvinylglycine (AVG) on preharvest drop, fruit quality, and maturation of 'Mclntosh' apples. II. Effect of timing and concentration relationships and spray volume. HortScience 39:1036-1041.

Islam, M.A., T.J. Blake, F. Kocacinar, and R. Lada. 2003. Ambiol, spermine, and aminoethoxyvinylglycine prevent water stress and protect membranes in Pinus strobus L. under drought. Trees (Berl.) 17:278-284.

Leskovar, D.I., J.C. Ward, R.W. Sprague, and A. Meiri. 2001. Yield, quality, and water use efficiency of melon are affected by irrigation and transplanting versus direct seeding. HortScience 36:286-291.

Locke, J.M., J.H. Bryce, and P.C. Morris. 2000. Contrasting effects of ethylene perception and biosynthesis inhibitors on germination and seedling growth of barley (Hordeum vulgare L.). J. Exp. Bot. 51:1843-1849.

Miccolis, V. and M.E. Saltveit. 1991. Morphological and physiological-changes during fruitgrowth and maturation of 7 melon cultivars. J. Amer. Soc. Hort. Sci. 116:1025-1029.

Rowan, K.S., W.B. McGlasson, and H.K. Pratt. 1969. Changes in adenosine pyrophosphates in cantaloupe fruit ripening normally and after treatment with ethylene. J. Exp. Bot. 20:145-155.

Schupp, J.R. and D.W. Greene. 2004. Effect of aminoethoxyvinylglycine (AVG) on preharvest drop, fruit quality, and maturation of 'McIntosh' apples. I. Concentration and timing of dilute applications of AVG. HortScience 39:1030-1035.

Shellie, K.C. 1999. Muskmelon (Cucumis melo L.) fruit ripening and postharvest quality after a preharvest spray of aminoethoxyvinylglycine. Postharv. Biol. Technol. 17:55-62.

Silva, J.A., T.S. da Costa, L. Lucchetta, L.J. Marini, M.R. Zanuzo, L. Nora, F.R. Nora, R.M. Twyman, and C.V. Rombaldi. 2004.
Characterization of ripening behavior in transgenic melons expressing an antisense 1-aminocyclopropane-1-carboxylate (ACC) oxidase gene from apple. Postharv. Biol. Technol. 32:263-268.

Smalle, J. and D. Van der Straeten. 1997. Ethylene and vegetative development. Physiol. Plant. 100:593-605.

Weyers, J.D.B. and N.W. Paterson. 2001. Plant hormones and the control of physiological processes. New Phytol. 152:375-407.

Yang, S.F. and N.E. Hoffman. 1984. Ethylene biosynthesis and its regulation in higher-plants. Annu. Rev. Plant Physiol. Plant Mol. Biol. 35:155-189.

Yu, Y.B., D.O. Adams, and S.F. Yang. 1979. 1-Aminocyclopropane-carboxylate synthase, a key enzyme in ethylene biosynthesis. Arch. Biochem. Biophys. 198:280-286.

Zheng, X.Y. and D.W. Wolff. 2000. Ethylene production, shelf-life and evidence of RFLP polymorphisms linked to ethylene genes in melon (Cucumis melo L.). Theor. Appl. Genet. 101:613-624. 